九州大学学術情報リポジトリ

Kyushu University Institutional Repository

\title{
Taxonomic Notes on the Indonesian Belonnotus Schultze (Coleoptera : Curculionidae), with Descriptions of Two New Species from Java
}

Yoshitake, Hiraku

Graduate School of Bioresource and Bioenvironmental Sciences, Kyushu University

Noerdjito, Woro A

Museum Zoologicum Bogori i iense, Zoological Division, Research Center for Biology, Indonesian Institute fo Science

https://doi.org/10.5109/2695

出版情報: ESAKIA. 44，pp.199-209，2004-03-31. Entomological Laboratory，Faculty of Agriculture, Kyushu University

バージョン：

権利関係 : 


\title{
Taxonomic Notes on the Indonesian Belonnotus Schultze (Coleoptera: Curculionidae), with Descriptions of Two New Species from Java*
}

\author{
Hiraku YoSHITAKE \\ Entomological Laboratory, Graduate School of Bioresource and Bioenvironmental Sciences, \\ Kyushu University, Fukuoka, 812-8581 Japan \\ and \\ Woro A. NOERDJITO \\ Museum Zoologicum Bogoriense, Zoological Division, Research Center for Biology, \\ Indonesian Institute of Science, Cibinong, 16911 Indonesia

\begin{abstract}
Belonnotus yukawai sp. n. and Belonnotus tibialis sp. n. are described from Java and Belonnotus floresanus (Heller) in the Lesser Sunda Islands is redescribed. A key to the three Indonesian species is provided, with photographs and illustrations of important features for each species.
\end{abstract}

Key words: Ceutorhynchinae, Mecysmoderini, Belonnotus floresanus.

\section{Introduction}

The genus Belonnotus Schultze, 1899 of the tribe Mecysmoderini, subfamily Ceutorhynchinae contains 17 species from the Oriental region (Colonnelli, 1992). Most of them are distributed in the Indian, Ceylonese, and Indo-Chinese subregions. From the Indo-Malayan subregion, no Belonnotus species has been recorded up to date but only Belonnotus floresanus (Heller, 1940) occurs on three islands, Flores, Sumba, and Sumbawa, in the Lesser Sunda Islands, eastern Indonesia. These islands are located zoogeographically in the Wallacea area and far from the main distribution range of the genus.

Such a distributional gap is apparently due to the lack of investigation in the IndoMalayan subregion, whose entomofauna is remarkably rich (e.g., Scriber, 1973; Pearson \& Cassola, 1992) and which is mainly composed of the Greater Sunda Islands on the

\footnotetext{
" Contribution from the Entomological Laboratory, Faculty of Agriculture, Kyushu University, Fukuoka (Ser. 5, No. 116).
} 
Sunda shelf. Since the western half of the Indonesian Archipelago is included in the Islands, we expect that a number of Belonnotus species will be discovered from Indonesia.

This study aims to fill the gap with descriptions of two new species from Java, together with a redescription of $B$. floresanus. A key to the three species is also given to promote future studies of the Indonesian Belonnotus fauna.

\section{Materials and Methods}

For this study, specimens preserved in the following two museums were examined: Museum Zoologicum Bogoriense, Zoological Division, Research Center for Biology, Indonesian Institute of Science, Cibinong (MZB); Naturhistorisches Museum, Basel (NHMB). Methods used here for descriptions are the same as those explained in Yoshitake \& Yamauchi (2002). Type specimens of two new species are deposited in MZB and specimens of $B$. floresanus are in NHMB.

\section{Belonnotus yukawai sp. n.}

(Figs. 1, 4, 5, 10, 13-16)

\section{Male.}

Body length: $2.68 \mathrm{~mm}$. Length of rostrum: $1.10 \mathrm{~mm}$. Maximum width across pronotum: $1.33 \mathrm{~mm}$. Pronotal length: $1.05 \mathrm{~mm}$. Length of pronotal process: $0.88 \mathrm{~mm}$. Maximum width across elytra: $2.03 \mathrm{~mm}$. Elytral length: $1.93 \mathrm{~mm}$. Sutural length: 0.95 $\mathrm{mm}$. For all measurements, $\mathrm{n}=1$. Habitus as shown in Fig. 1 .

Brown in general appearance; frons and pronotum darker; rostrum, antennae, and
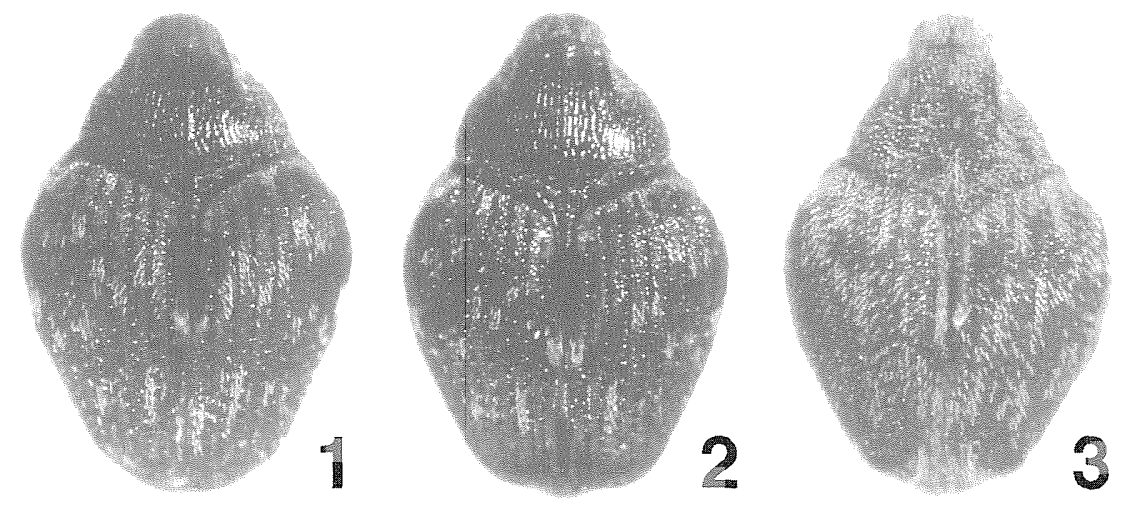

Figs. 1-3. Habitus of Belonnotus species. --- 1, B. yukawai; 2, B. tibialis; 3, B. floresanus. 

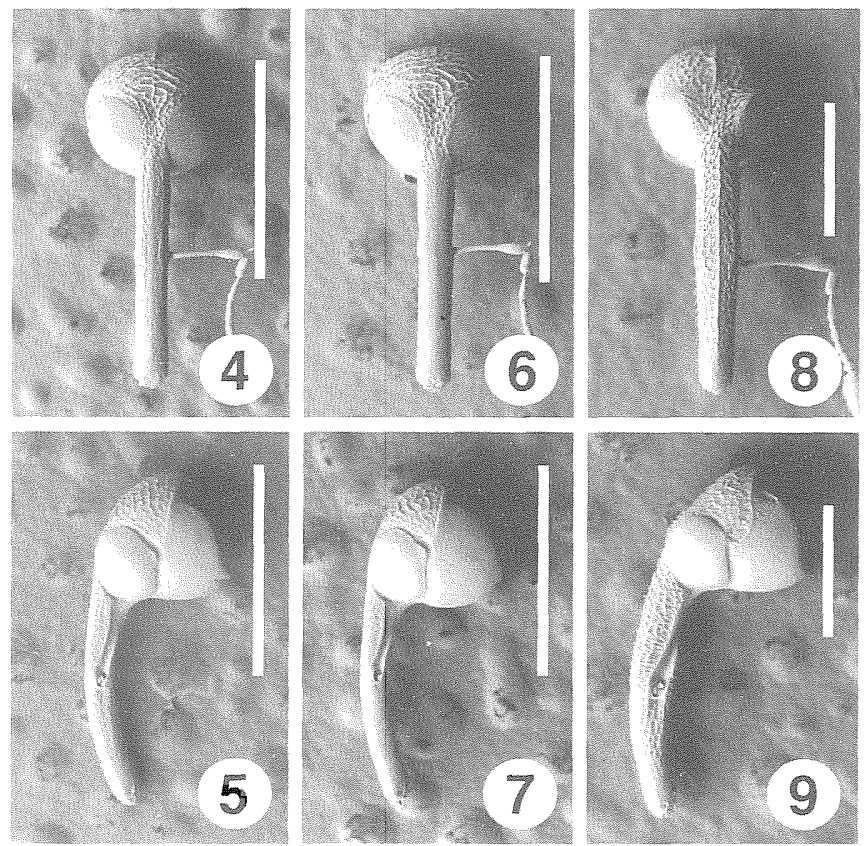

Figs 4-9. Heads of Belonnotus species. --- 4, 6, 8, Dorsal view; 5, 7, 9, lateral view. --- 4, 5, B. yukawai, male; 6, 7, B. tibialis, female; 8, 9, B. floresanus, male. Scale: 1.00 $\mathrm{mm}$ for $4-7 ; 0.50 \mathrm{~mm}$ for 8,9 .

tarsi lighter.

Head (Figs. 4, 5) clothed with yellowish gray narrow scales; each scale with truncate apex. Rostrum (Figs. 4, 5) moderately covered with minute hairs. Prothorax sparsely clothed with dark minute hair-like scales on disc; scales becoming denser and lighter at sides; each side with white stripe of lanceolate scales. Elytra densely covered with dark brown subrectangular scales, mixing with white scales; each interval with 2-4 rows of scales; interval I with velvety black patch of oval scales in basal $1 / 3$, followed posteriorly by small white patch; striae with row of white and dark brown narrow scales. Legs densely with white lanceolate and subrectangular scales; ventral surface of fore femora and dorsal surface of mid and hind pairs nearly naked; tibiae (Fig. 10) covered with dark hairs in apical $1 / 3$. Underside densely covered with white oval to lanceolate scales. Pygidium moderately clothed with yellowish gray hair-like scales.

Head (Figs. 4, 5) with short median carina on vertex, transversely wrinkledpunctured; forehead narrower than base of rostrum, shallowly depressed. Eyes (Figs. 4, 5) prominent weakly from outline of head, approximated anteriorly. Rostrum (Figs. 4, 5) 1.05 times as long as pronotum, evenly curved; dorsum minutely and moderately punc- 

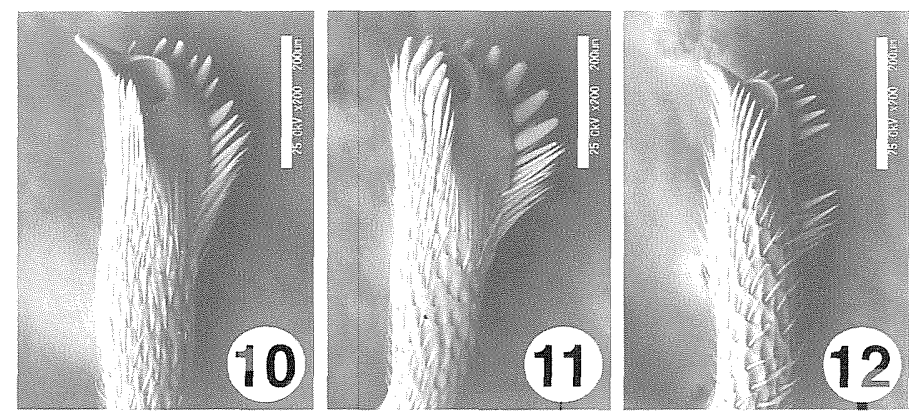

Figs. 10-12. Mid tibiae of Belonnotus species. --- 10, B. yukawai, male; 11, B. tibialis, female; 12, B. floresanus, male. Scale: $0.20 \mathrm{~mm}$.

tured, somewhat strongly shining; sides subparallel-sided in basal $1 / 4$, slightly narrowed to antennal insertion, subparallel-sided to apical $1 / 4$, then gradually broadened apically; antennal scrobes well-separated in entire length. Antennae robust, inserted just behind middle of rostrum; scape as long as funicular segments I, II, and III combined, produced in short lamina at apex, furnished with slender hair just behind lamina; funicle with segment I as long as II, II slender, slightly longer than III, III nearly twice as long as IV, IV slightly longer than and as wide as $\mathrm{V}, \mathrm{V}$ as long as and slightly narrower than VI, and VI as long as wide; club ovate, finely pubescent except basal 1/3. Prothorax transverse, 1.27 times as wide as long, widest at base, gently narrowed to middle, then convergent toward weak subapical constriction; dorsum flat, longitudinally wrinkled-punctured, strongly shining, with distinct median carina running from tip of pronotal process to apical margin; median carina flanked apically by 4 smooth lateral carinae; lateral carinae short, at most reaching apical $1 / 3$ of median one; apical margin evidently produced into obtuse angle at middle; basal margin fringed with row of large, deep, and subconfluent punctures; pronotal process very slender, 0.93 times as long as elytral suture, sharply projected; each side with non-squamate part just below scaly patch. Elytra cordiform, 1.05 times as wide as long, 1.53 times as wide as pronotum, widest just behind humeri, slightly narrowed to middle, then rapidly and straightly convergent toward smooth subapical calli; striae linear, straight, strongly shining; each puncture in striae elliptic, separated by the same distance as its diameter; intervals flat, much wider than striae, with 2-4 rows of minute granules, weakly shining. Legs robust; mid and hind femora weakly toothed; tibiae (Fig. 10) slightly dilated outwards in apical parts, fringed with small bristles at dilation; mid and hind tibiae mucronate at apex; mucrones of mid tibiae more conspicuous than those of hind ones. Sterna finely and densely punctured; prosternal canal deep, reaching level between middle of procoxae. Venter finely and densely punctured; ventrites I and II abruptly elevated, widely concave in middle; ventrite $\mathrm{V}$ widely and deeply concave on disc, bearing tuft of erect hairs at each 
side of concavity. Pygidium large, rounded-pentagonal, gently narrowed downwards, moderately punctured, faintly depressed in middle; upper flange smooth, lacking projection; lower margin faintly emarginate. Spiculum gastrale (Fig. 15) slender, slightly longer than aedeagal apodeme, strongly curved near apex. Tegmen (Fig. 16) with apodeme as long as width of tegminal ring. Aedeagal body (Figs. 13, 14) stout, gradually broadened to apical $1 / 3$, then gently convergent apically, bluntly projected at apex; apodeme slender, 1.50 times as long as body. Endophallus (Figs. 13, 14) longer than aedeagal apodeme, with minute spicules near base and with complex sclerites in middle.

Female. Unknown.

Type material. Holotype, male (dissected), Mt. Tangkubanperahu, 1,200-1,500 m, West Java, iii. 1934, F. C. Drescher.

Distribution. Indonesia (the Greater Sunda Islands: Java).

Remarks. Belonnotus yukawai is similar to Belonnotus tricarinatus Schultze, 1899 from India in having the narrower forehead than base of rostrum, the eyes approximated anteriorly (Fig. 4), the flat pronotum with wrinkled punctation, etc. However, $B$. yukawai is readily distinguished from $B$. tricarinatus by the dorsal surface lacking patches of white ovate scales, the median carina of pronotum flanked apically by four lateral carinae, and the slenderer pronotal process. In addition, B. yukawai does not have any remarkable characteristics on the male ventrite II except for a shallow median concavity, whereas in B. tricarinatus the ventrite is furnished with a pair of prominent scaly tufts at sides of the concavity.

Etymology. This species is named after Prof. J. Yukawa (ELKU), who is one of the most eminent experts on galling insects and has been engaged for many years in faunistic studies of Indonesian insects.

\section{Belonnotus tibialis sp. $\mathrm{n}$.}

(Figs. 2, 6, 7, 11, 17-19)

\section{Femalle.}

Body length: 2.60-2.85 mm. Length of rostrum: 1.11-1.23 mm. Maximum width across pronotum: $1.33-1.45 \mathrm{~mm}$. Pronotal length: $0.98-1.08 \mathrm{~mm}$. Length of pronotal process: $0.75-0.85 \mathrm{~mm}$. Maximum width across elytra: $1.93-2.15 \mathrm{~mm}$. Elytral length: 1.88-2.08 mm. Sutural length: 0.85-0.95 mm. For all measurements, $\mathrm{n}=2$. Habitus as shown in Fig. 2.

Black in general appearance; rostrum and antennae dark brown.

Rostrum (Figs. 6,7) 1.13-1.14 times as long as pronotum; dorsum with strong luster; punctures becoming smaller and sparser in apical 2/3; sides subparallel-sided in basal 
$1 / 5$, slightly narrowed to antennal insertion, subparallel-sided to apical $1 / 4$, then gradually broadened apically. Antennae inserted behind middle of rostrum. Pronotum slightly wider, $1.34-1.36$ times as wide as long; pronotal process $0.88-0.89$ times as long as elytral suture. Elytra 1.03 times as wide as long, 1.45-1.48 times as wide as pronotum. Legs very stout; tibiae (Fig. 11) strongly dilated outwards in apical parts, fringed with large bristles at dilation, lacking mucro. Ventrites I and II slightly inflated; ventrite V flattened on disc, covered only with general scales. Pygidium small, depressed, minutely punctured. Genitalia as in Figs. 17-19. Otherwise practically as in B. yukawai. Male. Unknown.

Type material. Holotype, female, Mt. Botol, 1,530-1,700 m, Gunung Halimun National Park, West Java, 27. v. - 2. vi. 1999, T. Ueno and M. Rofik Sofyan. Paratype, female (dissected), same data as the holotype.

Distribution. Indonesia (the Greater Sunda Islands: Java).

Remarks. This species is very similar to $B$. yukawai in general appearance, but is readily distinguishable from it by the tibial apices fringed with stout bristles (Fig. 11).

Etymology. The specific name refers to the characteristic tibiae.

\section{Belonnotus floresanus (Heller, 1940)}

(Figs. 3, 8, 9, 12, 20-26)

Mecysmoderes floresanus Heller, 1940: 105 (type locality: Flores, Sumbawa).

Belonnotus floresanus Colonnelli, 1992: 402 (Sumba).

Male.

Body length: $2.25-2.35 \mathrm{~mm}$. Length of rostrum: 1.04-1.10 mm. Maximum width across pronotum: $1.13-1.15 \mathrm{~mm}$. Pronotal length: $0.88-0.93 \mathrm{~mm}$. Length of pronotal process: $0.70-0.75 \mathrm{~mm}$. Maximum width across elytra: $1.73-1.78 \mathrm{~mm}$. Elytral length: 1.63-1.68 mm. Sutural length: $0.63-0.68 \mathrm{~mm}$. For all measurements, $\mathrm{n}=2$. Habitus as shown in Fig. 3.

Dark brown in general appearance; apex of rostrum, antennae, apical margin of prothorax, and tarsi reddish brown.

Head clothed with yellowish hair-like scales; each scale long, robust, and more or less erect. Rostrum rather densely covered with scales as ones on head from base to antennal insertion and then with fine hairs to apex. Prothorax clothed with scales as ones on head; scales becoming darker medially; dorsum with small patch of white lanceolate scales at outer side of each lateral carina; each side with white stripe of lanceolate scales. Elytra mottled with yellowish gray and dark brown narrow scales; scales truncate apically; intervals each with 2-4 rows of scales; interval I with white or 


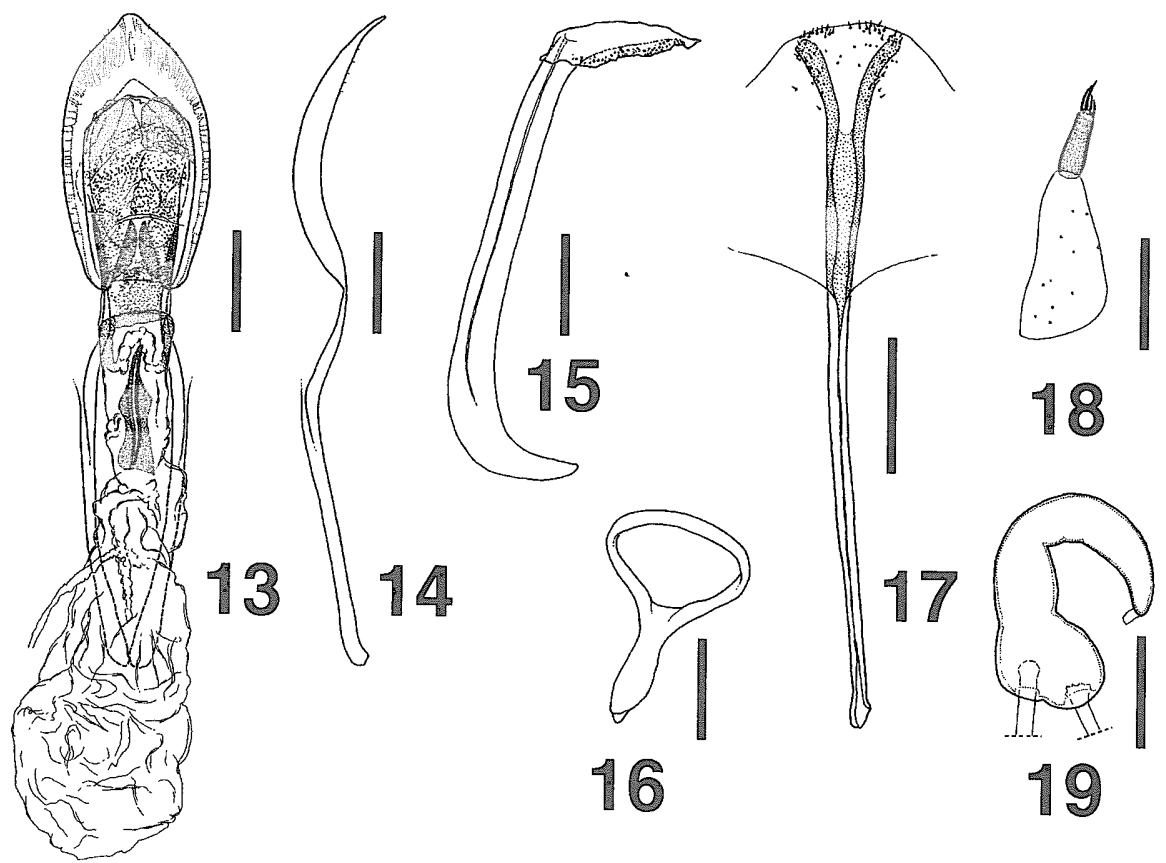

Figs. 13-19. Male genitalia of B. yukawai and female genitalia of B. tibialis. --- 13, Aedeagus, dorsal view; 14, ditto, lateral view; 15, sternite IX; 16, tegmen; 17, sternite VIII; 18, stylus and coxite; 19, spermatheca. ---13-16, B. yukawai; 17-19, B. tibialis. Scale: $1.00 \mathrm{~mm}$ for $13-17 ; 0.50 \mathrm{~mm}$ for 18,19 .

yellowish patch of oval scales in basal $1 / 3$; striae with row of yellowish gray narrow scales, mixing with dark ones. Femora densely with scales as ones on elytra, mixing with white lanceolate scales; dorsal surface of mid and hind pairs nearly naked; femoral teeth covered by lanceolate scales. Tibiae covered with suberect hair-like scales; scales replaced with hairs apically. Lateral pieces of meso- and metasterna with lanceolate white scales, in addition to yellowish gray narrow ones. Underside densely covered with white oval to lanceolate scales. Pygidium clothed with lanceolate white scales, except upper $1 / 3$ with hair-like and narrow ones.

Head (Figs. 8, 9) reticulately punctured, with long median carina extending from vertex to basal part of forehead; forehead flat, nearly as wide as base of rostrum. Eyes somewhat strongly prominent from outline of head, not approximated anteriorly. Rostrum 1.18 times as long as pronotum, abruptly curved in apical 1/3; dorsum carinate medially, coarsely and reticulately punctured, weakly shining; sides subparallel-sided from base to antennal insertion, then gradually narrowed apically, subparallel-sided in 


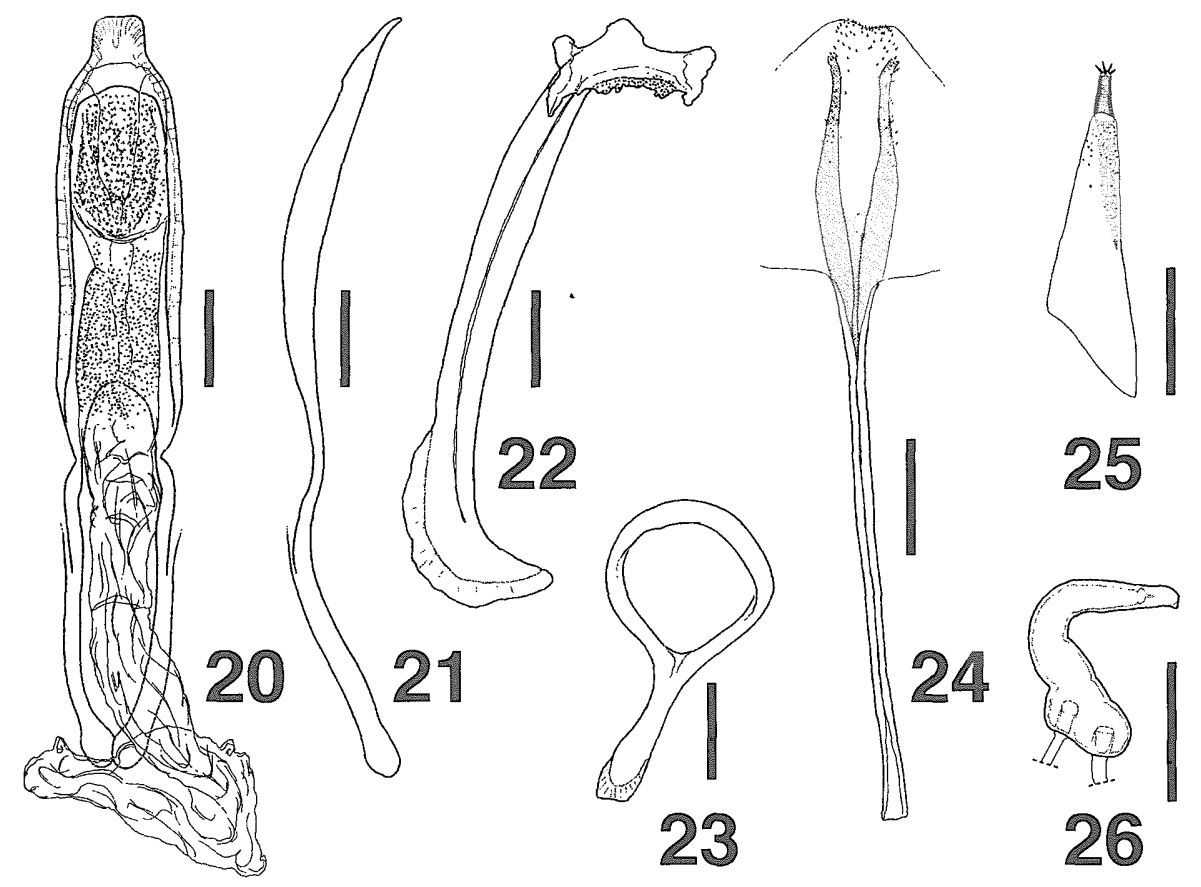

Figs. 20-26. Male and female genitalia of B. floresanus. --- 20, Aedeagus, dorsal view; 21, ditto, lateral view; 22, sternite IX; 23, tegmen; 24, sternite VIII; 25, stylus and coxite; 26, spermatheca. ---20-23, male; 24-26, female. Scale: $1.00 \mathrm{~mm}$ for 20-25; $0.50 \mathrm{~mm}$ for 26 .

apical 1/4; antennal scrobes fused basally on ventral surface of rostrum. Antennae inserted before middle of rostrum; scape slightly shorter than funicle, rounded and furnished with hair at apex; funicle with segment I slightly longer than II, II slender, as long as III, III nearly twice as long as IV, IV slightly longer and narrower than V, V as long as and much narrower than VI, and VI evidently shorter than wide; club ovate, finely pubescent except basal 1/3. Prothorax 1.24-1.28 times as wide as long, widest at base, gently narrowed to apical $1 / 3$, then convergent toward strong subapical constriction; dorsum moderately covex, reticulately punctured, weakly shining; median carina flanked apically by 2 precipitous lateral carinae; lateral carinae long, extending to apical 1/2 of median one; apical margin faintly produced into obtuse angle at middle; basal margin fringed with row of large, deep, and subconfluent punctures; pronotal process 1.10-1.11 times as long as elytral suture; each side with less-squamate part just below scaly patch. Elytra 1.06 times as wide as long, 1.53-1.55 times as wide as pronotum, widest just behind humeri, slightly narrowed to middle, then rapidly and 
straightly convergent toward rugged subapical calli; striae linear, straight, weakly shining; each puncture in striae elliptic, separated by the same distance as its diameter; intervals flat, much wider than striae, reticulately punctured, weakly shining. Legs robust; mid and hind femora relatively strongly toothed; tibiae fringed with slender setae apically; fore tibiae strongly dilated outwards in apical 1/4; mid tibiae (Fig. 12) apically externally sinuate, each sharply mucronate at apex; hind tibiae apically externally sinuate. Sterna finely, deeply and reticulately punctured; prosternal canal deep, reaching level between middle of procoxae. Venter with punctures as ones on sterna; ventrites I and II successively elevated, inflated in middle; ventrite V with small median concavity. Pygidium small, pentagonal, strongly narrowed downwards, reticulately punctured; upper flange smooth, lacking projection; lower margin straight. Spiculum gastrale (Fig. 22) longer than aedeagal body or its apodeme, strongly expanded and curved near apex. Tegmen with slender apodeme; apodeme nearly as long as width of tegminal ring (Fig. 23). Aedeagal body (Figs. 20, 21) slender, subparallelsided to apical $1 / 4$, then rapidly narrowed apically, parallel-sided just before and truncate at apex; apodeme much shorter than body. Endophallus (Figs. 20, 21) nearly as long as aedeagal body and its apodeme taken together, with minute spicules in basal $1 / 2$, lacking conspicuous sclerites.

Female.

Body length: $2.48-2.50 \mathrm{~mm}$ (mean $2.49 \mathrm{~mm}$ ). Length of rostrum: $1.10-1.20 \mathrm{~mm}$ (1.16 $\mathrm{mm})$. Maximum width across pronotum: $1.20-1.25 \mathrm{~mm}(1.23 \mathrm{~mm})$. Pronotal length: $0.95-1.00 \mathrm{~mm}(0.98 \mathrm{~mm})$. Length of pronotal process: $0.75-0.80 \mathrm{~mm}(0.78 \mathrm{~mm})$. Maximum width across elytra: $1.88-1.89 \mathrm{~mm}(1.89 \mathrm{~mm})$. Elytral length: $1.75-1.78 \mathrm{~mm}$ $(1.77 \mathrm{~mm})$. Sutural length: $0.78-0.80 \mathrm{~mm}(0.79 \mathrm{~mm})$. For all measurements, $\mathrm{n}=3$.

Rostrum barely slenderer, 1.16-1.20 times as long as pronotum. Antennae inserted at middle of rostrum. Prothorax 1.25-1.28 times as wide as long; pronotal process 1.001.03 times as long as elytral suture. Elytra 1.06-1.07 times as wide as long, 1.50-1.51 times as wide as pronotum. Mid tibiae simple, not mucronate at apex. Ventrite V smooth, lacking concavity. Genitalia as in Figs. 24-26. Otherwise practically as in male.

Specimens examined. 2 males and 2 females, Bondo Kodi, West Sumba, 12. viii. 1949, Bühler and Sutter. 1 female, Waimangura, West Sumba, 15. viii. 1949, Bühler and Sutter. All specimens were identified in 1989 by Dr. E. Colonnelli.

Distribution. Indonesia (the Lesser Sunda Islands: Flores, Sumba, Sumbawa).

Remarks. Belonnotus floresanus is distinctive enough not to be confused with other congeners from Indonesia in having the smaller body with dense vestiture and reticulate punctation (Fig. 3), the wider forehead (Fig. 8), the stout rostrum with a distinct median carina (Figs. 8, 9), and the more convex pronotum. 


\section{Key to the Indonesian Species}

1(4) Body larger, 2.60-2.85 mm in length. Forehead shallowly depressed, narrower than base of rostrum. Eyes approximated anteriorly. Rostrum devoid of distinct carina, evenly curved. Pronotum flat, longitudinally wrinkled-punctured, sparsely clothed with dark minute scales. Median carina of pronotum flanked in apical $1 / 3$ by 4 smooth lateral carinae. Elytra mostly clothed with dark brown subrectangular scales, mottled with white spots.

2(3) Tibiae weakly dilated outwards in apical parts and fringed with small bristles at dilation. B. yukawai

3(2) Tibiae strongly dilated outwards in apical parts and fringed with large bristles at dilation. B. tibialis

4(1) Body smaller, 2.25-2.50 mm in length. Forehead flat, nearly as long as base of rostrum. Eyes not approximated anteriorly. Rostrum carinate, abruptly curved in apical $1 / 3$. Pronotum moderately convex, reticulately punctured, densely clothed with light hair-like scales that become darker medially. Median carina of pronotum flanked in apical $1 / 2$ by 2 precipitous lateral carinae. Elytra densely clothed with yellowish gray and dark brown narrow scales.

B. floresanus

\section{Acknowledgements}

It is our great pleasure to dedicate this paper to Prof. J. Yukawa on the commemorative occasion of his retirement from Kyushu University in March 2004. We thank Dr. M. Brancucci (NHMB) for the loan of specimens. One of us (HY) appreciates Prof. Emeritus K. Morimoto, Associate Prof. O. Tadauchi, and Assistant Prof. S. Kamitani (ELKU) for their constant guidance. This study was supported in part by a grant from JSPS Research Fellowships for Young Scientists (to HY).

\section{References}

Colonnelli, E., 1992. Notes on the Ceutorhynchinae tribe Mecysmoderini Wagner, 1938 (Coleoptera, Curculionidae). Ent. Basil., 15: 395-422.

Heller, K. M., 1940. Indomalayische Rüsselkäfer II (Coleoptera: Curculionidae). Arb. morphol. taxon. Ent. Berlin-Dahlem, 7 : 92-113, 2 pls.

Pearson, D. L. \& F. Cassola, 1992. World-wide species richness patterns of tiger beetles (Coleoptera: Cicindelidae): indicator taxon for biodiversity and conservation studies. Conserv. Biol., 6: 376-391.

Schultze, A., 1899. Drei neue indische Ceuthorrhynchinen. Dtsch. ent. Z., 1899: 187- 
191.

Scriber, J. M., 1973. Latitudinal gradients in larval feeding specialization of the world Papilionidae (Lepidoptera). Psyche, 80: 355-373.

Yoshitake, H. \& T. Yamauchi, 2002. A new genus of the Oriental tribe Mecysmoderini (Coleoptera, Curculionidae, Ceutorhynchinae), with descriptions of two new species from Indonesia and Malaysia. Spec. Bull. Jpn. Soc. Coleopterol., Tokyo, (5): 413-423. 
